\title{
Customer orientation on new product activities and performance from the contract manufacturer's viewpoint
}

\author{
B.C.Y. Lee ${ }^{a}$ and F.T.C. Kou ${ }^{\text {b* }}$ \\ ${ }^{a}$ Graduate Institute of Business Administration, Fu Jen Catholic University, 510, Chung Cheng Road, \\ ${ }^{\mathrm{b}}$ HsinChuang, New Taipei City, 24205, Taiwan, Tel: 886-952557696 \\ *To whom all correspondence should be addressed. \\ fredonef@hotmail.com
}

\begin{abstract}
Studies have suggested the positive effect of customer orientation on superior performance. However, these studies have not shown how to covert customer orientation into superior performance through new product development (NPD) activities. The purpose of this study was to fill the gap between customer orientation and new product performance and elucidate the mediating influence of product launch, product development capability, and innovativeness on the relationship between customer orientation and new product performance. From the contract manufacturer's perspective, it was proposed that customer orientation toward new product performance affects NPD activities. Focus was placed on product launch because the launch stage is the most expensive and riskiest aspect of NPD activities. Focus was also given to product development capability, which facilitates superior product performance. Product innovativeness also plays a crucial role in building competitive advantage. NPD activities include product launch, product development capability, and product innovativeness. We used a questionnaire to collect data to test the postulated research model and hypotheses from project, account and product managers in the high-tech industry. The results demonstrated the strong positive effect of customer orientation on NPD activities, and NPD activities play crucial roles as mediators between customer orientation and new product performance.
\end{abstract}

\section{Introduction}

Customer orientation is a fundamental component of marketing (King, 1965) and the foundation and subscale of market orientation (Narver \& Slater, 1990). For the past two decades, customer orientation has been studied as a single dimension of market orientation (Jaworski \& Kohli, 1993; Narver \& Slater, 1990). Customer orientation is critical for firms to obtain profit (Favalgi, Whipple, Ghosh, \& Young, 2005). Empirical research has supported the premise that customer relationships positively affect new product performance (Atuahene-Gima, 1995). Strong competition offers customers multiple choices. Thus, a firm must analyze and adequately respond to customer preferences and changes to ensure that customers choose the firm's offerings rather than competitors' offerings (Yang, Wang, Zhu, \& $\mathrm{Wu}, 2012$ ). Studies have considered the relationship between customer orientation culture and new product performance. However, they have not shown how to convert customer orientation into superior performance through new product development (NPD) activities.

NPD is a process that involves initiation, coordination, product completion, production (Acur, Kandemir \& Boer, 2012). Scholars asserted that NPD activities are linked consistently to new product performance (Henard \& Szymanski, 2001). Firms conduct NPD activities from the innovation stage to product development, and then to the product launch stage. A substantial amount of new product literature has presented a discussion of innovation and development capability in NPD. A meta-analysis showed that only $4 \%$ of articles on product development and product innovativeness focus on product launch (Montoya-Weiss \& Calantone, 1994). New product launch is an expensive, risky, and time-consuming stage in the NPD process (Bowersox, Stank \& Daugherty, 1999). High investment in intensive $\mathrm{R} \& \mathrm{D}$ resources for new products is considered unique and enables firms to gain a competitive advantage. However, poor product launch remains a contributing factor to lack of success (Lee \& O'Connor, 2003) and is a critical component of several NPD activities, except for product development capability and product innovativeness.

Previous research has supported the notion that a marketoriented culture drives NPD activities; market orientation has positive effects on idea generation and creation as well as market testing, and facilitates the identification of new market opportunities (Atuahene-Gima, 1995; Troy, Szymanski \& Varadarajan, 2001). Customer orientation is a foundation of market orientation (Narver \& Slater, 1990). A customer-oriented firm is focused on serving crucial customers and obtaining information to develop products that meet customer expectations (Slater \& Narver, 1998). Previous NPD literature has supported that firms learn and receive knowledge from their customers for the NPD process (Koufteros, Vonderembse \& Jayaram, 2005). This indicates that a customer-oriented culture is crucial in NPD activities. Firms can create superior value for customers by developing new products, and NPD activities are the basis for obtaining new product performance. 
The mediating influence of product launch, product development capability, and innovativeness on the relationship between customer orientation and new product performance was examined. Firms must arrange frequent meetings with customers for product launch activities and hold additional meetings related to market trends (Di Benedetto, 1999). A proper launch strategy is necessary for communicating product advantages to customers (Lee, Lin, Wong \& Calantone, 2011). Empirical studies have indicated close relationships among delivery of customer value, launch timing, and product performance (Cooper \& Kleinschmidt, 1990; Lilien \& Yoon, 1990), implying that a customer-orientated culture improves new product performance if a lean launch strategy is executed efficiently. Customer-oriented firms must also possess superior NPD capabilities and leverage NPD capability to enhance product profit and market share based on customer knowledge and information. Lukas and Ferrell (2000) supported the relationship between customer orientation and product innovativeness, and scholars have reported the positive effect of product innovativeness on new product performance (Katz, 2000; Tidd, Bessant \& Pavitt, 2001). A high degree of product innovativeness is associated with product advantage, unique selling points, and high customer satisfaction. For instance, brand customers ${ }^{1}$, such as HP, Dell, Sony, and Acer, outsource R\&D and manufacturing to contract manufacturers ${ }^{2}$. Because contract manufacturers have built a close relationship with brand customers, contract manufacturers must execute NPD activities effectively to increase the number of orders based on brand customers' needs and preferences. Therefore, product launch, product development capability, and product innovativeness are crucial mediators between customer orientation and new product performance, particularly in the high-tech industry. Numerous new-product projects have been introduced based on customer orientation. These are the key reasons that the high-tech industry was chosen for this study.

The purpose of this study was to investigate the relationships among customer orientation, NPD activities, and performance in the high-tech industry. The research comprises two parts. First, a literature review and an interview with managers were conducted and the relationship among customer orientation, NPD activities, and new product performance was investigated. NPD activities include product launch, product development capability, and product innovativeness. A conceptual model with seven hypotheses was formulated. Second, field data from project, account, and product managers in the hightech industry were used to test the postulated hypotheses. A sample of 229 related managers was involved in this study,

\footnotetext{
${ }^{1}$ Brand owner: In this study, a brand owner is defined as a branded electronics buyer (large international OEM customer or ODM customer)

${ }^{2}$ Contract manufacturer: In this study, a contract manufacturer is defined as a supplier possessing an original equipment manufacturer (OEM) or original design manufacturer (ODM) business
}

and the findings and managerial implications and suggestions are discussed.

\section{Literature review}

Based on the literature review and interview with 12 managers, hypotheses on the relationship between customer orientation and new product performance, as well as the mediating influences of product launch, product development capability, and innovativeness on this relationship were proposed. However, literature considering the effects of customer orientation and NPD activities on new product performance is scarce. The hypotheses are explained in detail in the following section.

\section{Customer Orientation and NPD Activities}

Market orientation is a business culture that efficiently creates superior customer value. Market orientation comprises three components: customer orientation, competitor orientation, and interfunctional coordination. Customer orientation is the foundation of market orientation (Narver \& Slater, 1990), is typically researched as a dimension of market orientation (Jaworski \& Kohli, 1993; Narver \& Slater, 1990), and is regarded as fundamental to marketing (King, 1965). Customer orientation includes information dissemination and acquisition and involves creating superior value for customers continuously through an understanding of target buyers (Kohli \& Jaworski, 1990). In the marketing literature, discussions of customer orientation are focused on marketing activities conducted for the end goal of customer satisfaction (McKitterick, 1957). Customer orientation is particularly crucial for firms collecting information on customer preferences to create superior customer value (Wu, Tsai \& Fu, 2012). Narver and Slater (1990) indicated that customer orientation drives marketing activities and helps to create superior value for customer needs and wants. Customer orientation affords firms the ability and motivation to respond to customer needs and the chance to gain new product advantage through a focus on customer needs and satisfaction (Gatignon \& Xuereb, 1997). Consequently, a customer-oriented firm has the capability to identify and respond adequately to current and future customer requirements.

NPD is a process that involves initiation, coordination, product completion, production (Acur, Kandemir \& Boer, 2012). Scholars have asserted that the NPD activities of organizing and external demands affect new product performance (Hsieh, Tsai \& Hultink, 2006; Laugen, Boer \& Acur, 2006). Bowersox et al. (1999) indicated two primary activities in new product introductions: product launch and product development. New product launch is conceived, implemented, and resourced as a factor of NPD success (Cooper, 1999). Product launch for NPD involves planning the commercialization of new products in detail (Hultink, Griffin, Hart \& Robben, 1997), and product development capabilities are critical for contract manufacturers who seek to secure their current brand customers (Swink \& Mabert, 2000). The ability of a firm to improve its offerings to create 
an advantage in the competitive market is critical for product development capabilities (Autio, Sapienza \& Almeida, 2000). Marketing studies have greatly emphasized product innovativeness in NPD activities, and certain NPD research has supported the positive effect of product innovativeness on new product performance (Henard \& Szymanski, 2001; Katz, 2000; Tidd et al., 2001). A firm with a customer-oriented culture is focused on serving crucial customers and obtaining information to develop products that meet customer expectations (Slater \& Narver, 1998). Previous NPD literature has supported that firms learn and receive knowledge from their customers for the NPD process (Koufteros et al., 2005). Based on previous research, it was proposed that NPD activities, including product launch, product development capability, and product innovativeness, are essential to achieving new product performance based on customer orientation.

In a lean launch strategy, firms use few resources, gradually increase manufacturing, and maintain low inventory for product rollout (Calantone, Di Benedetto \& Stank, 2005). The key principle of a lean launch strategy is postponement. Risk and costs are highly related to product launch decisions. Postponement involves releasing a product at the latest possible point in the product marketing process and postponing inventory changes. Postponement is not realized completely because it requires time related to customer information (Bowersox et al., 1999). This principle improves lead time and operation flexibility and reduces inventory, risk, and cost (Calantone et al., 2005).

Firms must arrange frequent meetings with customers and hold additional meetings related to product launch activities and market trends (Di Benedetto, 1999). Product advantages must be communicated to customers when executing a product launch (Lee et al., 2011). Contract manufacturers possessing an understanding of brand customers' requirements for product design can obtain precise forecasts according to customer orientation and easily manage the execution of the product launch. Thus, the following hypothesis was proposed:

\section{H1: Customer orientation is positively related to the lean launch of new products.}

A customer-oriented firm focuses on serving crucial customers and obtaining information to develop products according to customer expectations (Slater \& Narver, 1998). The ability of a firm to improve its offerings to create advantage in the competitive market is critical for success and NPD capabilities (Autio et al., 2000). Previous NPD literature has supported the notion that firms learn and receive knowledge from their customers in the NPD process (Koufteros et al., 2005) and require knowledge from internal and external sources in the product-design process (Calantone, Cavusgil, Schmidt \& Shin, 2004). Firms that build a customer-oriented organization and have NPD capabilities respond well to acquiring the latest knowledge and intelligence (Kohli \& Jaworski, 1990) and can obtain additional knowledge or information from the customer side to improve their product development capability. Previous literature has supported that customer-oriented firms possess superior NPD capabilities. Thus, the following hypothesis was proposed:

\section{H2: Customer orientation is positively related to product development capability.}

Innovativeness is the fundamental opportunity to modify original firm procedures (Kimberly, 1979). Danneels and Kleinschmidt (2001) defined product innovativeness from the firm and customer perspectives. The customer perspective includes product attributes, risks, and behavioral changes. Studies have extensively examined the relationship between customer orientation and innovation (Baker \& Sinkkula, 2005; Jaworski \& Kohli, 1993; Slater \& Narver, 1994). In the debate in favor of customer orientation, its numerous effects on innovation have been emphasized. Scholars have indicated the positive effect of customer orientation on innovative products (Lukas \& Ferrell, 2000). Customer orientation supports firms in identifying innovation opportunities in the current domain (cf. Atuahene-Gima \& Ko, 2001). Understanding customers in depth is crucial to exploring the latest needs and the new technology used to satisfy them (Slater \& Narver, 1998). However, other studies have provided customer orientation results related to reactive strategies and incremental product innovativeness (Atuahene-Gima, 2005; Baker \& Sinkula, 2005). This study focused on the contract manufacturerbrand owner relationship. Knowledge obtained in a timely manner and technologies obtained from external sources and internal capabilities are integrated with new ideas to improve the success of product innovativeness (Hollenstein, 1996). Thus, it was assumed that a customer orientation improves product innovativeness, which ultimately satisfies customer needs. Therefore, the following hypothesis was proposed:

\section{H3: Customer orientation is positively related to product} innovativeness.

\section{New product performance of contract manufacturers}

A poor launch strategy often causes products to be unsuccessful (Stryker, 1996). The term "good time to market" indicates that projects are developed and launched efficiently and on time (Griffin \& Page, 1996). Firms that launch projects on time for emerging global markets create opportunities to increase returns and meet global market demands (de Brentani, Kleinschmidt \& Salomo, 2010). The launch of a new product is always considerably expensive (Langerak, Hultink \& Robben, 2004), signifying that properly executed lean launches save costs and ultimately improve new product performance. To target customer responses, the most favorable course of action is to improve timing for tactical launch decisions (Hultink \& Robben, 1999; Langerak et al., 2004). Bowersox et al. (1999) suggested that lean launch execution minimizes inventory deployment, enables products to be introduced at lower costs, and increases profitability. A lean launch strategy improves time to market, lead time, and operation flexibility, and reduces inventory, risk, and costs (Calantone 
et al., 2005). Cooper and Kleinschmidt (1987) suggested that performing a greater number of NPD activities increases chances of product success. In the high-tech industry, launching on time is associated with large market share and high price premiums. An effective launch strategy enhances aspects of market performance including launch objectives, product position, and market segment (Guiltinan, 1999). Delaying products results in a low market share in the long term (Robinson \& Chiang, 2002; Song, Di Benedetto \& Zhao, 1999), and competitors overcome firms that delay product launch (Crawford \& Di Benedetto, 2008). In summary, lean launch critically affects new product success. Thus, the following hypothesis was proposed:

\section{H4: Product lean launch is positively related to new product performance.}

Product development capabilities are critical for contract manufacturers that seek to secure their current brand customers (Swink \& Mabert, 2000) and are a key factor for businesses to enjoy long-term success (Brown \& Eisenhardt, 1995). NPD research has indicated that firms obtain customer knowledge in the NPD process to enhance new product performance (Joshi \& Sharma, 2004; Koufteros et al., 2005). Firms that collect information for potential innovations and convert this information into NPD increase interest (Ahuja \& Lampert, 2001). Therefore, effective product development capabilities are associated with superior levels of new product performance, greater product advantage over major competitors, and greater gains in return on investment, revenue, and increased market share. Thus, the following hypothesis was proposed:

\section{H5: Product development capability is positively related to new product performance.}

Studies on new product development have indicated the positive effect of product innovativeness on new product performance (Henard \& Szymanski, 2001; Katz, 2000; Tidd et al., 2001). Kleinschmidt and Cooper (1991) argued that highly innovative products positively affect new product performance. Product innovativeness offers new functions to customers and rapid gains in the market share with product advantage. Although the defect rate is high in highly innovative products, they continue to generate more profit compared with incrementally innovative products (Sheremata, 2004). Brand customers prefer to cooperate with a contract manufacturer possessing superior innovation capability because this relationship enables them to undertake new projects to gain a product advantage in the market. Thus, the following hypothesis was proposed:

H6: Product innovativeness is positively related to new product performance.

Customer orientation is critical for firms to gain a profit (Favalgi et al., 2005). Empirical research supports the premise that customer relationships positively affect business performance (Deshpande, Farley \& Webster, 1993) and new product performance (Atuahene-Gima, 1995). Strong competition offers customers multiple choices; therefore, a firm must analyze and efficiently respond to customer preferences and changes to ensure that customers chose its offerings over those of competitors (Yang et al., 2012). To offer superior value for increased revenue, a firm must respond to customer needs (Kohli \& Jaworski, 1990). Firms prefer to meet customer needs in the market and increase revenue by focusing on the relevant factors of achievement (Cooper, Edgett \& Kleinschmidt, 2001). In summary, customer orientation positively supports firms by enabling them to understand customer preferences and offer the appropriate products in advance to gain a greater market share and profit. Thus, the following hypothesis was proposed:

H7: Customer orientation is positively related to new
product performance.

\section{Conceptual Model}

The conceptual model and hypotheses of this study are shown in Figure 1.

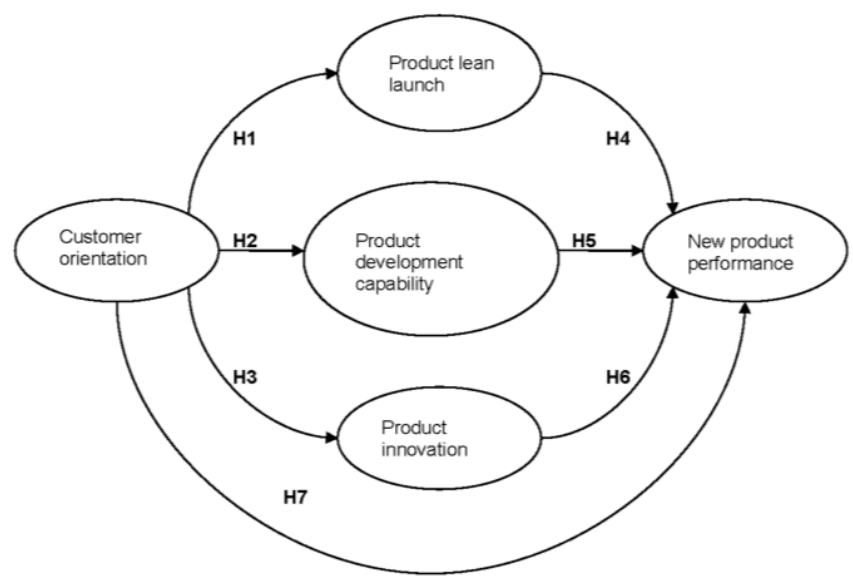

Figure 1: Conceptual model

\section{Methodology}

Contract manufacturer managers in Taiwan were chosen to participate in this study and to test the postulated hypotheses. Because contract manufacturers are a crucial aspect of the global supply chain and they build close relationships with numerous international brand customers in the high-tech industry, contract manufacturers design and manufacture products based on brand customers' needs and preferences. According to the production share ranking of the Market Intelligence Centre (MIC) for Taiwanese IT firms, the notebooks, PCs, motherboards, and liquid-crystaldisplay (LCD) monitors produced by Taiwanese IT firms are ranked first worldwide. Taiwanese firms are well-known as original equipment manufacturers (OEM) and original design manufacturer (ODM) suppliers through the valueadded chain in the global high-tech industry. Most brand customers (HP, Dell, Sony, and Apple) use outsourcing strategies for product design and production with Taiwanese contract manufacturers. In several instances, Foxconn Technology Group was the number one contract 
manufacturer worldwide for various types of electronic products. Quanta Computer recently supplied cloud server equipment to Google, Amazon, and Facebook directly. The 2011 MIC reported that international procurement offices (IPOs) spent US\$90 billion on electronic products in Taiwan.

A questionnaire was used to collect data for testing the postulated research model. The related managers (project, account, and product managers) directly cooperated with brand customers with expert product knowledge in the hightech industry. A survey was delivered to the appropriate managers, and the structural equation model (SEM) was used to test the conceptual model. AMOS 18 was used to estimate the structural coefficients and to test the hypotheses.

\section{The Measures}

All of the constructs were measured using multi-item 5point Likert-type scales in this study. The constructs were developed based on previous literature. To improve the validity of the measurement items, a two-step process was used. First, the drafted questionnaires were discussed with 12 project managers and, second, a pre-test of a sample of 24 project and product managers was conducted.

Customer orientation was measured using a multi-item scale. Narver and Slater (1990) supported the concept that market orientation is a second-order scale consisting of three subscales: customer orientation, competitor orientation, and interfunctional coordination. To measure customer orientation, the measured items were adapted from Langerak (2001) and the scale of Narver and Slater (1990). Regarding new product performance, a multi-item scale was drawn from Song and Parry (1999). This scale assessed whether the new product achieved sales, profit goals, and customer satisfaction.

Product lean launch was measured by using a multi-item scale developed by Calantone and Di Benedetto (2012). The scale measured whether the firm responded quickly enough for customers, kept inventory costs low, and employed flexible techniques to launch new products in a timely manner. A product development capability scale was adopted from Huang and Chu (2010) to measure a firm's capability to develop a new product effectively and efficiently. To measure product innovativeness, a multi-item scale was drawn from Atuahene-Gima (1996) and Lee and O'Connor (2003), measuring the extent to which the new product had benefits, new features, and a unique advantage compared with competitors.

\section{The Sample}

In the sampling frame, a list of managers from high-tech firms listed on the Taiwan Stock Exchange (TSE) was obtained. The focus was on contract manufacturers that conducted OEM or ODM business with brand customers for a broad spectrum of notebook, PC, server, smartphone, tablet, LCD monitor, TV, and networking product types. The appropriate respondents were contacted in the contract manufacturer samples and questionnaires were delivered to them directly through mail and e-mail. A total of 687 questionnaires were distributed to the appropriate respondents directly, and 229 usable questionnaires were returned for analysis, representing a response rate of $33 \%$. Sample characteristics are presented in Table 1.

Table 1: Sample characteristics $(n=229)$

\begin{tabular}{lcc}
\hline Number of employees & Number of firms & Percentage \\
\hline Under 100 & 3 & $10 \%$ \\
Over 100-500 & 6 & $19 \%$ \\
Over 500-1000 & 8 & $26 \%$ \\
Over 1000 & 12 & $39 \%$ \\
No response & 2 & $6 \%$ \\
Total & 31 & $100 \%$ \\
\hline & & \\
\hline Product Sector & Number of Respondents & Percentage \\
Computer products & 68 & $30 \%$ \\
Display products & 41 & $18 \%$ \\
Mobile phone products & 33 & $14 \%$ \\
Server products & 23 & $10 \%$ \\
Networking products & 37 & $16 \%$ \\
Electronic accessories & 27 & $12 \%$ \\
Total & 229 & $100 \%$ \\
\hline
\end{tabular}

\section{Reliability}

Both the Cronbach's $\alpha$ and the reliability formula (Fornell \& Lacker, 1981) were used to assess the scale reliability of each construct in the model. Table 2 indicates the Cronbach's $\alpha$, reliability and average variance extracted (AVE) scores. The reliability values of all construct measures were greater than 0,70 , and all of the Cronbach's $\alpha$ values were between 0,75 and 0,87 , indicating that the measures have good internal consistency.

\section{Validity}

The AVE is used to assess convergent validity (Fornell \& Lacker, 1981). As shown in Table 2, the AVE of the five constructs was higher than 0,5 and supports the convergent validity. For discriminant validity, Table 3 indicates that the square root of the AVE was higher than the correlations between constructs, indicating that the measures exhibited adequate discriminant validity (Fornell \& Lacker, 1981). 
Table 2: Scale reliability and AVE scores

\begin{tabular}{lcccc}
\hline Construct & Item No & Cronbach $\alpha$ & Composite reliability & AVE \\
\hline Customer orientation & 6 & 0,878 & 0,877 & 0,545 \\
Product Lean launch & 3 & 0,861 & 0,862 & 0,677 \\
Product development capability & 3 & 0,808 & 0,802 & 0,575 \\
Product innovativeness & 3 & 0,753 & 0,760 & 0,515 \\
New product performance & 3 & 0,870 & 0,856 & 0,668 \\
\hline
\end{tabular}

Table 3: Descriptive statistics and correlations

\begin{tabular}{|c|c|c|c|c|c|c|c|}
\hline & Mean & SD & 1 & 2 & 3 & 4 & 5 \\
\hline 1. Customer orientation & 3,878 & 0,605 & $\mathbf{0 , 7 3 8}$ & & & & \\
\hline 2. Product Lean launch & 3,638 & 0,784 & $0,494 * *$ & $\mathbf{0 , 8 2 3}$ & & & \\
\hline 3. Product development capability & 3,373 & 0,760 & $0,563 * *$ & $0,591 * *$ & 0,758 & & \\
\hline 4. Product innovativeness & 4,003 & 0,605 & $0,467 * *$ & $0,364 * *$ & $0,443 * *$ & 0,718 & \\
\hline 5.New product performance & 3,140 & 0,909 & $0,430 * *$ & $0,471 * *$ & $0,546 * *$ & $0,431 * *$ & $\mathbf{0 , 8 1 7}$ \\
\hline
\end{tabular}

Note: Numbers in bold denote the square root of the average variance extracted (AVE); $* * p<, 01$.

\section{Hypothesis test}

AMOS 18 was used to estimate the model parameters for the proposed conceptual model. Figure 2 shows that the overall model fitness indexes were good (GFI $=0,949$, AGFI $=0,925, p$ value $=, 526$, chi-square $=113,34$ d.f. $=$ 115]). Most of the hypothesized main effects were found to be significant at the $\alpha=0,05$ level. The positive effects of customer orientation on lean launch performance were found with $\mathrm{H} 1$. The path coefficient of customer orientation to lean launch was $0,641(\mathrm{t}=7,138, \mathrm{p}<, 01)$. Thus, $\mathrm{H} 1$ was supported. The path coefficient of customer orientation to product development capability was $0,800(\mathrm{t}=8,201$, $\mathrm{p}<$ $, 01)$. The results showed that customer orientation has a significant and positive effect on product development capability; thus $\mathrm{H} 2$ was supported. The path coefficient of customer orientation to product innovativeness was $0,481(\mathrm{t}$ $=6,367, \mathrm{p}<, 01)$, indicating the significant and positive effect of customer orientation on product innovativeness, thus supporting H3.

The path coefficient of lean launch to new product performance was $0,324(\mathrm{t}=2,484, \mathrm{p}<, 05)$. According to $\mathrm{H} 4$, lean launch drives new product performance; therefore, H4 was supported, indicating the positive effects of lean launch execution on new product performance. The path coefficient of product development capability to product performance was $0,332(\mathrm{t}=2,028, \mathrm{p}<, 05)$, showing a positive effect of new product capability on new product performance. Thus, H5 was supported. Regarding H6, the path coefficient of product innovativeness to new product performance was $0,450(\mathrm{t}=2,925, \mathrm{p}<, 01)$. Product innovativeness had a strong direct effect on new product performance, supporting H6. According to H7, customer orientation is related to new product performance. However, the positive effect of customer orientation on new product performance was not supported; thus, H7 was not supported. Regarding H7, the path coefficient of lean launch to new product performance was $0,160(\mathrm{t}=0,922, \mathrm{p}>, 05)$.

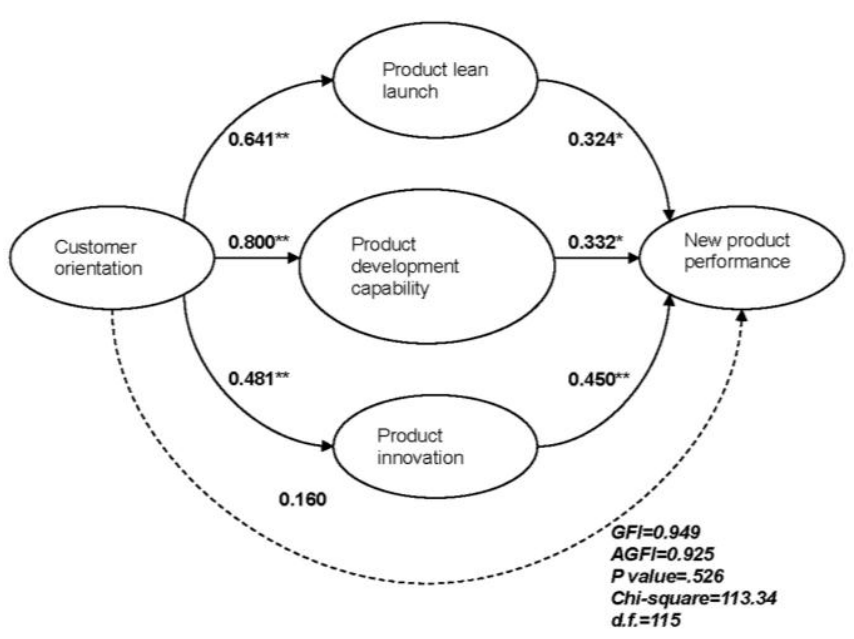

Figure 1: Analysis results of structural equation model $(* * \mathbf{p}<, 05)$

\section{Discussion}

SEM analysis indicated that most of the hypotheses (H1 to H6) related to NPD activities are significant, although $\mathrm{H} 7$ was not supported. This study demonstrates that customer orientation has a positive effect on the lean launch of new products. Contract manufacturers could acquire information and knowledge from brand customers, supporting the understanding of customers' product preferences and forecasts, thereby reducing the cost of inventory management, improving the product-launch schedule, and enabling customer responses to be quickly obtained when launching new products. Customer orientation also improves new product development capabilities. Contract manufacturers can develop new products with positive features based on brand customer requirements. Customer orientation drives contract manufacturers to develop new products within a short period, reduce budget costs caused by intense competition, and maintain quality. Customer orientation has a direct effect on product innovativeness. Atuahene-Gima and Ko (2001) suggested that customer orientation supports firms in finding innovative 
opportunities in the current domain. These results reveal that contract manufacturers invest most $R \& D$ resources in developing innovative products with unique functions for customers and obtain knowledge from customers. Consequently, managers must understand what customers want and their purchasing behavior, and consider their suggestions for enhancing NPD activities.

Product lean launch plays a mediating role in new product performance. Lean launch has a direct positive effect on new product performance, which is consistent with the view that its execution minimizes inventory deployment, facilitates the introduction of low-cost products, and increases profitability (Bowersox et al., 1999). This implies that lean launch execution enables maintaining minimum inventories with low costs, producing quick responses for customer satisfaction, and introducing new products on time to customers. For these reasons, obtaining a greater number of customer orders allows higher profits and sales targets for new products to be realized. The results indicate the positive effects of product development capability on new product performance. Contract manufactures that have a high level of product development capability can design specific new products to attract the attention of brand customers and ensure that NPD is finalized in a time period that satisfies market demand. The price is competitive in the OEM and ODM businesses. Brand customers of contract manufacturers that maintain a high standard of quality benefit by purchasing new product from the same contract manufacturer continuously. This study demonstrates that product innovativeness drives new product performance. Contract manufacturers build a trusting relationship with brand customers and learn about each other's innovative products. Product innovativeness enhances new or unique functions and enables brand customers with a product advantage to increase their market share and profit. Consequently, brand customers prefer to cooperate with the same contract manufacturers for future innovation projects.

Customer orientation affects new product performance through lean launch, product development capability, and product innovativeness; however, the direct effect on new product performance is non-significant. This directly contrasts to expectations based on previous studies. Cooper et al. (2001) suggested that firms prefer to meet customer needs in the market and increase revenue by achieving the right focus. Adopting a customer-oriented culture might not be an efficient tactic for improving new product performance directly. However, managers could initially enhance NPD activities based on customer orientation. Lean launch execution results in lower costs and a reduction in inventories. Product development capability could provide high-quality products for customers, and product innovativeness could offer unique products to support customers' advantage in the market. Finally, NPD activities could efficiently and effectively improve new product performance for contract manufacturers.

\section{Limitations and suggestions for future research}

There are some limitations to this study. First, future research could focus on the mediating effects of different types of product innovativeness and launch strategy. Second, other dimensions might affect lean launch performance. Future studies could examine cross-functional teams, inventory strategies, and product complexity. Third, this study was focused on the contract manufacturer's perspective for collecting data. Research of the brand customer's perspective could be conducted. In addition, the sample of manufacturers was chosen from the high-tech industry only. Future research could explore other industries or compare the results among various industries.

\section{Conclusion}

In this study, the relationships among customer orientation, NPD activities, and new product performance were considered. Contract manufacturers that have lean launch execution ability, product development capability, and innovativeness can provide high levels of new product performance based on customer orientation in the high-tech industry. The model can serve as an instrument for managers to understand customer preferences when improving new product performance through managing NPD activities. However, a customer-oriented culture indirectly improves new product performance. Leveraging NPD activities toward new product performance is crucial.

\section{NOTES}

[1] Brand owner: In this study, a brand owner is defined as a branded electronics buyer (large international OEM customer or ODM customer).

[2] Contract manufacturer: In this study, a contract manufacturer is defined as a supplier possessing an original equipment manufacturer (OEM) or original design manufacturer (ODM) business.

\section{References}

Acur, N., Kandemir, D. \& Boer, H. 2012. 'Strategic alignment and new product development: Drivers and performance effects', Journal of Product Innovation Management, 29: 304-18.

Ahuja, G. \& Lampert, C.M. 2001. 'Entrepreneurship in the large corporation: A longitudinal study of how established firms create breakthrough inventions', Strategic Management Journal, 22: 521-43.

Atuahene-Gima, K. 1995. 'An exploratory analysis of the impact of market orientation on new product performance: A contingency approach', Journal of Product Innovation Management, 12: 275-93.

Atuahene-Gima, K. 1996. 'Differential potency of factors affecting innovation performance in manufacturing and 
services firms in Australia', Journal of Product Innovation Management, 13: 35-52.

Atuahene-Gima, K. 2005. 'Resolving the capability-rigidity paradox in new product innovation', Journal of Marketing, 69(4): 61-83.

Atuahene-Gima, K. \& Ko, A. 2001. 'An empirical investigation of the effect of market orientation and entrepreneurship orientation alignment on product innovation', Organization Science, 12(1): 54-74.

Autio, E., Sapienza, H. \& Almeida, J. 2000. 'Effects of age at the entry, knowledge intensity and imitability on international growth', Academy of Management Journal, 43: 909-24.

Baker, W.E. \& Sinkula, J.M. 2005. 'Market orientation and the new product paradox', Journal of Product Innovation Management, 22: 483-502.

Bowersox, D.J., Stank, T.P. \& Daugherty, P.J. 1999. 'Lean launch: Managing product introduction risk through response-based logistics', Journal of Product Innovation Management, 16: 557-68.

Brown, S.L. \& Eisenhardt, K.M. 1995. 'Product development: Past research, present findings and future directions', Academy of Management Review, 20: 343-78.

Calantone, R.J. \& Di Benedetto, C.A. 2012. 'The role of lean launch execution and launch timing on new product performance', Journal of Academy of Marketing Science, 40: $526-38$.

Calantone, R.J., Cavusgil, S.T., Schmidt, J.B. \& Shin, G.C. 2004. 'Internationalization and the dynamics of product adaptation: An empirical investigation', Journal of Product Innovation Management, 22: 185-98.

Calantone, R.J., Di Benedetto, C.A. \& Stank, T.P. 2005. 'Managing the supply chain implications of launch'. In Kenneth, B., Kahn, G.C. \& Griffin, A. (Eds.), The PDMA handbook of new product development. ( $2^{\text {nd }}$ Edition). Hoboken: Wiley, pp. 466-478.

Cooper, R.G. 1999. 'The invisible success factors on product innovation', Journal of Product Innovation Management, 16: 115-33.

Cooper, R.G. \& Klcinschmidt, E.J. 1987. 'New products: What separates winners from losers?' Journal of Product Innovation Management, 4: 169-84.

Cooper, R.G. \& Kleinschmidt, E.J. 1990. New products: The key factors in success. Chicago, IL: American Marketing Association.

Cooper, R., Edgett, S.J. \& Kleinschmidt, E.J. 2001. 'Portfolio management for new product development:
Results of an industry practice study', $R \& D$ Management, 31: $361-80$.

Crawford, C.M. \& Di Benedetto, C.A. 2008. New products management $\left(9^{\text {th }}\right.$ Edition). Burr Ridge: Irwin/McGraw-Hill.

Danneels, E. \& Kleinschmidt, E.J. 2001. 'Product innovativeness from the firm's perspective: Its dimensions and their relation with project selection and performance', Journal of Product Innovation Management, 18: 357-73.

De Brentani, U., Kleinschmidt, E.J. \& Salomo, S. 2010. 'Success in global new product development: Impact of strategy and the behavioral environment of the firm', Journal of Product Innovation Management, 21: 184-98.

Deshpande, R., Farley, J.U. \& Webster, F.E. 1993. 'Corporate culture, customer orientation, and innovativeness in Japanese firms: A quadrad analysis', Journal of marketing, 57: 23-7.

Di Benedetto, C.A. 1999. 'Identifying the key factors in new product launch', Journal of Product Innovation Management, 16: 530-44.

Favalgi, R.G., Whipple, T.W., Ghosh, A.K. \& Young, R.B. 2005. 'Market orientation, strategic flexibility, and performance: Implications for services providers', Journal of Service Marketing, 19: 212-21.

Fornell, C. \& Larcker, D.F. 1981. 'Evaluating structural equation models with unobservable variables and measurement error', Journal of Marketing Research, 18(1): 39-50.

Gatignon, H. \& Xuereb, J.M. 1997. 'Strategic orientation of the firm and new product performance', Journal of Marketing Research, 34(1): 77-90.

Griffin, A. \& Page, A.L. 1996. 'PDMA success measurement project: Recommended measures for product development success and failure', Journal of Product Innovation Management, 13(6): 478-96.

Guiltinan, J.P. 1999. 'Launch strategy, launch tactics, and demand outcomes', Journal of Product Innovation Management, 16: 509-29.

Henard, D.H. \& Szymanski, D.M. 2001. 'Why some new products are more successful than others', Journal of Marketing Research, 38(3): 362-75.

Hollenstein, H. 1996. 'A composite indicator of a firm's innovativeness: An empirical analysis based on survey data for Swiss manufacturing', Research Policy, 25: 633-45.

Hsieh, M.H., Tsai, K.H. \& Hultink, E.J. 2006. 'The relationships between resource configurations and launch strategies in Taiwan's IC design industry: An exploratory study', Journal of Product Innovation Management, 23: 259-73. 
Huang, Y.T. \& Chu, W. 2010. 'Enhancement of product development capabilities of OEM suppliers: Inter- and intraorganisational learning', Journal of Business \& Industrial Marketing, 25: 147-58.

Hultink, E.J. \& Robben, H.S.J. 1999. 'Launch strategy and new product performance: An empirical examination in the Netherlands', Journal of Product Innovation Management, 16: $545-56$.

Hultink, E.J., Griffin, A., Hart, S. \& Robben, H.S.J. 1997. 'Industrial new product launch strategies and product development performance', Journal of Product Innovation Management, 14: 243-57.

Jaworski, B. \& Kohli, A.K. 1993. 'Market orientation: Antecedents and consequences', Journal of Marketing, 57(3): 53-70.

Joshi, A.W. \& Sharma, S. 2004. 'Customer knowledge development: Antecedents and impact on new product performance', Journal of Marketing, 68(4): 47-59.

Katz, R. 2000. Managing creativity and innovation. Boston: Harvard Business School Press.

Kimberly, J.R. 1979. 'Issues in the creation of organizations: Initiation,innovation, and institutionalization', Academy of Management Journal, 22: 437-57.

King, R. 1965. 'The marketing concept'. In Schwartz, G. (Ed.), Science in marketing. New York: John Wiley \& Sons, pp. 70-97.

Kleinschmidt, E.J. \& Cooper, R.G. 1991. 'The impact of product innovativeness on performance', Journal of Product Innovation Management, 8: 240-51.

Kohli, A.K. \& Jaworski, B.J. 1990. 'Market orientation: The construct, research propositions, and managerial implications', Journal of Marketing, 54(2): 1-18.

Koufteros, X., Vonderembse, M. \& Jayaram, J. 2005. 'Internal and external integration for product development: The contingency effects of uncertainty, equivocality, andplatform strategy', Decision Sciences, 36: 97-133.

Langerak, F. 2001. 'Effects of market orientation on the behaviors of salespersons and purchasers, channel relationships, and performance of manufacturers', International Journal of Research in Marketing, 18: 221-34.

Langerak, F., Hultink, E.J. \& Robben, H.S.J. 2004. 'The impact of market orientation, product advantage, and launch proficiency on new product performance and organizational performance', Journal of Product Innovation Management, 21: 79-94.

Laugen, B.T., Boer, H. \& Acur, N. 2006. 'The new product development motives and practices of Miles and Snow's prospectors, analyzers and defenders', Creativity and Innovation Management, 15: 85-95.

Lee, Y. \& O'Connor, G. 2003. 'The impact of communication strategy on launching new products: The moderating role of product innovativeness', Journal of Product Innovation Management, 20: 4-21.

Lee, Y., Lin, B.W., Wong, Y.Y. \& Calantone, R.J. 2011. 'Understanding and managing international product launch: A comparison between developed and emerging markets', Journal of Product Innovation Management, 28(S1): 10420.

Lilien, G.L. \& Yoon, E. 1990. 'The timing of competitive market entry: An exploratory study of new industrial practices', Management Science, 36: 568-85.

Lukas, B.A. \& Ferrell, O.C. 2000. 'The effect of market orientation on product innovation', Academy of Marketing Science Journal, 28: 239-48.

McKitterick, J. 1957. What is the marketing thought and action? Chicago, IL: American Marketing Association.

Montoya-Weiss, M.M. \& Calantone, R.J. 1994. 'Determinants of new product performance: A review and meta-analysis', Journal of Product Innovation Management, 11: $397-418$.

Narver, J. \& Slater, S. 1990. 'The effect of a market orientation on business profitability, Journal of Marketing', 54(4): 20-35.

Robinson, W.T. \& Chiang, J. 2002. 'Product development strategies for established market pioneers, early followers, and late entrants', Strategic Management Journal, 23: 85566.

Sheremata, W.A. 2004. 'Competing through innovation in network markets: Strategies for challengers', Academy of Management Review, 29: 359-77.

Slater, S.F. \& Narver, J.C. 1994. 'Does competitive environment moderate the market orientation performance relationship?' Journal of Marketing, 58(1): 46-55.

Slater, S.F. \& Narver, J.C. 1998. 'Customer-led and marketoriented: Let's not confuse the two', Strategic Management Journal, 19: 1001-6.

Song, M., Di Benedetto, C.A. \& Zhao, Y.L. 1999. 'Pioneering advantages in manufacturing and service industries: Empirical evidence from nine countries', Strategic Management Journal, 20: 811-36.

Song, X.M. \& Parry, M.E. 1999. 'Challenges of managing the development of breakthrough products in Japan', Journal of Operations Management, 17: 665-88. 
Stryker, J.D. 1996. 'Launching a new business-to-business product.' In Rosenau, M.D. Jr., Griffin, A., Castellion, G. \& Anschuetz, N. (Eds.). The PDMA handbook of New product development. New York: Wiley, pp.363-80.

Swink, M.L. \& Mabert, V.A. 2000. 'Product development partnerships: Balancing the needs of OEMs and suppliers', Business Horizons, 43(3): 59-68.

Tidd, J., Bessant, J. \& Pavitt, K. 2001. Managing innovation. ( $2^{\text {nd }}$ Edition). New York: John Wiley \& Sons.

Troy, L.C., Szymanski, D.M. \& Varadarajan, P.R. 2001. 'Generating new product ideas: An initial investigation of the role of market information and organizational characteristics', Journal of the Academy of Marketing Science, 29: 89-101.

Wu, W.Y., Tsai, C.C. \& Fu, C.S. 2012. 'The relationships among internal marketing, job satisfaction, relationship marketing, customer orientation and organizational performance: An empirical study of TFT-LCD companies in Taiwan', Human Factors and Ergonomics in Manufacturing \& Service Industries, 23: 436-49.

Yang, Y., Wang, Q., Zhu, H. \& Wu, G. 2012. 'What are the effective strategic orientations for new product success under different environments? An empirical study of Chinese businesses', Journal of Product Innovation Management, 29: 166-79.

\section{Appendix}

\section{Measurement Scales of Constructs}

(Respondents were requested to answer the following questions, choosing the most appropriate option from a continuum of strongly agree to strongly disagree on a Likert 5-point scale.)

\section{Customer orientation (Langerak ,2001; Narver \&} Slater,1990)

- -Our firm gathers information about customers'needs.

- -Our firm consults customers to improve the quality of service.

- -Our firm handles customers' complaints well.

- -Our firm involves customers in decisions that affect the relationship.

- -Our firm looks for ways to offer customers more value.

- -Our firm treats customers as partners.-We do not mind owing each other favors.

\section{Product development capability (Yen-Tsung Huang \&} Wenyi Chu.,2010)

- -Development of products with high quality.

- $\quad$-Product development at high speed.

- $\quad$-Product development at low cost.

Product innovativeness (Atuahene-Gima,1996; Lee \& Colarelli O'Connor ,2003)

- $\quad$ The innovation addresses a wholly new customer benefit.

- $\quad$ The innovation offers customers unique advantages over competitor products.

- $\quad$ The innovation introduced completely new features to the market.

Lean launch (Calantone \& Di Benedetto, 2012)

- -Work-in-process inventories were well-controlled.

- -QR (Quick Response) or ECR (Efficient Customer Response) programs were in force.

- $\quad$-Flexible manufacturing techniques were used on this project

New product performance(Song \& Parry,1999)

- $\quad$ The product has achieved our sales goal

- $\quad$ The product has achieved our profit goal

- -Customers are very satisfied with the product performance 